\title{
Multiparametric evaluation of prostatic tumors using magnetic resonance imaging: spectroscopy and diffusion
}

\author{
Avaliação multiparamétrica de tumores da próstata por ressonância magnética: espectroscopia \\ e difusão
}

\author{
Ana Teresa Varandas ${ }^{1}$, Diana Esteves ${ }^{1}$, Marina Pires de Matos ${ }^{1}$, Rui Campos ${ }^{1}$, João Carlos Costa ${ }^{3}$, Hugo \\ Alexandre Ferreira ${ }^{2}$ \\ 'ERISA - Escola Superior de Saúde Ribeiro Sanches, Rua do Telhal aos Olivais, n8 - 8a, 1900-693 Lisboa \\ ${ }^{2}$ Instituto de Biofísica e Engenharia Biomédica, Faculdade de Ciências da Universidade de Lisboa, Lisboa, Portugal \\ ${ }^{3}$ Clínica Dr. João Carlos Costa, Viana do Castelo, Portugal \\ e-mail: hhferreira@fc.ul.pt
}

\begin{abstract}
Currently, ultrasonography-guided biopsy is the most widely used method in the detection of prostate cancer (PCa). However, the sensitivity of the technique is low (39\% - 52\%). In this work, Magnetic Resonance Spectroscopy (MRS) and Diffusion-Weighted Imaging (DWI) will be studied regarding their ability to detect and localize prostatic lesions. Eighteen male patients, who underwent prostate biopsy were studied. A total of 11 patients were diagnosed with PCa, with a modal Gleason Score (GS) of 7; 4 had chronic prostatitis and 3 had negative histological results. Spectroscopy and diffusion by MRI were used to study prostate lesions, and the parenchyma of the central and healthy peripheral zones of the gland. Values of choline/citrate (Cho/Ci) and Apparent Diffusion Coefficient (ADC) were measured. Descriptive and comparative statistics were applied.

In patients with $\mathrm{PCa}$, differences were observed between the mean values of $\mathrm{Cho} / \mathrm{Ci}(\mathrm{p}=0,000)$ and $\mathrm{ADC}(\mathrm{p}=0,000)$ in lesions and healthy peripheral parenchyma. In patients with negative histology, there were differences observed between the mean values of $\mathrm{Cho} / \mathrm{Ci}$ in suspected lesions and healthy peripheral parenchyma $(\mathrm{p}=0,006)$. The $\mathrm{Cho} / \mathrm{Ci}$ of lesions was positively correlated with GS ( $\mathrm{rS}=0,677 ; \mathrm{p}=0,045)$. Results show that MRS and DWI are able to identify and locate tumor lesions and suspected areas, thus having the potential to guide biopsy in the study of PCa.
\end{abstract}

Keywords: Prostate Cancer; Magnetic Resonance Imaging; Spectroscopy; Diffusion

\section{Resumo}

Actualmente, a biópsia por Ecografia é o meio mais utilizado na detecção do Adenocarcinoma da Próstata (AdP). Contudo, a sensibilidade da técnica na localização é baixa (39\% - 52\%). Pretende-se avaliar a capacidade das técnicas de Espectroscopia por Ressonância Magnética (MRS) e Imagem ponderada em Difusão (DWI) na detecção e localização de lesões prostáticas .

Estudou-se uma amostra de 18 doentes do sexo masculino com idade média de 68.2 anos, submetidos a biópsia prostática. 11 doentes apresentaram diagnóstico de AdP com Gleason Score (GS) de 7, 4 apresentaram prostatite crónica e 3 apresentaram resultado histológico negativo. Utilizaram-se as técnicas de MRS e DWI para estudar lesões prostáticas, e os parênquimas das zonas central e periférica saudável da glândula. Mediram-se os valores de rácio colina/citrato (Cho/ Ci) e do coeficiente de difusão aparente (ADC). Foi aplicada estatística descritiva e comparativa.

Nos doentes com AdP, observaram-se diferenças entre os valores médios de Cho/ $\mathrm{Ci}(\mathrm{p}=0,000)$ e $\mathrm{ADC}(\mathrm{p}=0,000)$ das lesões e das zonas periféricas de parênquima saudável. Nos doentes com histologia negativa, observou-se diferenças entre os valores médios de $\mathrm{Cho} / \mathrm{Ci}$ na lesão e o parênquima saudável $(\mathrm{p}=0,006)$. O valor $\mathrm{Cho} / \mathrm{Ci}$ da lesão correlacionou-se positivamente com o GS ( $\mathrm{rS}=0,677 ; \mathrm{p}=0,045)$. Os resultados mostram que as técnicas MRS e DWI permitem identificar e localizar lesões tumorais e suspeitas, tendo assim potencial para orientar a biópsia no estudo do AdP.

Palavras-chave: Adenocarcinoma da Próstata; Ressonância Magnética; Espectroscopia; Difusão 


\section{Introduction}

Nowadays, prostate cancer ( $\mathrm{PCa}$ ) is considered a public health problem. It is one of the cancers with the highest incidence in males ( 1 in 6 men develop PCa) [1]. Detection is usually performed primarily by a rectal examination and by measurement of the prostate specific antigen (PSA). If changes occur, it is necessary to do a biopsy to obtain a histological evaluation of the prostate tissue. From the biopsied tissue it is possible to do a histological quantification, the Gleason Score (GS). The biopsy is usually performed by collecting pieces of different areas of the prostate. This procedure is guided by Transrectal Ultrasound. However, the sensitivity of biopsy for detection of $\mathrm{PCa}$ is low (39\% - $52 \%$ ) [2], thus the importance of seeking other ways to increase the sensitivity. Magnetic Resonance Imaging (MRI) has been used to identify and characterize prostate lesions [3]. In particular, MRI spectroscopy (MRS) has allowed a more complete and accurate assessment of prostate lesions using the metabolites choline and citrate [4]. It has been observed that the use of MRS in addition to the conventional evaluation by MRI increases the sensitivity and specificity in detecting malignant lesions [4].

This study was done in a Portuguese clinical environment and aimed to explore the potential of MRI/MRS in the localization of prostate lesions in order to guide the biopsy procedure, using the quantification of the ratio choline/citrate $(\mathrm{Cho} / \mathrm{Ci})$ and apparent diffusion coefficient (ADC). Tests were performed comparing mean values, and correlations were done between ratios of $\mathrm{Cho} / \mathrm{Ci}$ and $\mathrm{ADC}$ of the different zones of the prostate in order to verify their compliance with histological diagnosis and GS.

\section{Prostate examination by MRI}

In a MRI prostate exam, four types of studies are usually performed: morphological, perfusion, diffusion and spectroscopy. The morphological study is useful for visualizing the zonal architecture of the prostate. This is done using the sequences T1 and T2-weighted Turbo Spin Echo (TSE).

In a T1-weighted sequence the prostate appears with a very uniform and intermediate signal intensity, while on a T2-weighted sequence there are differences in the regions of the gland: the peripheral region appears with a hyperintensity in contrast to the central and transition zones which have a lower signal intensity (Figure 1) $[3,5,6]$.

A perfusion study is performed using a gadolinium intravenous contrast agent and is based on tumor neo-

\section{Introdution}

Actualmente, o Adenocarcinoma da Próstata (AdP) é considerado um problema de saúde pública. É um dos tipos de cancro com maior incidência no sexo masculino (1 em cada 6 homens desenvolvem AdP)[1]. A sua detecção é normalmente efectuada primariamente por toque rectal e através da medição do antigénio específico da próstata (PSA). Caso se verifiquem alterações, é necessário uma avaliação histológica através de biópsia prostática. A partir do tecido biopsado é realizada uma quantificação histológica, o Gleason Score (GS). A biópsia é normalmente realizada através da colheita de fragmentos das diversas zonas prostáticas, sendo este procedimento guiado por Ecografia Trans-Rectal. Contudo a sensibilidade da biópsia para a detecção do AdP é baixa (39 \% - 52 \%)[2], daí a importância de se procurar outros meios que permitam aumentar essa sensibilidade.

A técnica de Ressonância Magnética (RM) tem sido usada para identificar e caracterizar lesões prostáticas [3]. Em particular, a técnica de Espectroscopia por RM (MRS) tem permitido fazer uma avaliação mais completa e precisa recorrendo à avaliação dos metabolitos colina e citrato [4]. Observou-se que a utilização de MRS em adição à avaliação convencional por RM permite aumentar a sensibilidade e especificidade na detecção de lesões malignas [4].

Com este estudo, pretendeu-se explorar numa unidade clínica portuguesa o potencial da RM/MRS na localização de lesões prostática com vista a guiar o procedimento de biópsia, recorrendo à quantificação do rácio colina/citrato (Cho/Ci) e do coeficiente de difusão aparente (ADC). Em particular, foram realizados testes de comparação de valores médios e correlações entre os valores medidos de espectroscopia, o rácio $\mathrm{Cho} / \mathrm{Ci}$, e difusão (ADC) das diferentes zonas da próstata, de forma a verificar a sua concordância com o diagnóstico histológico e GS.

\section{Estudos da Próstata por RM}

Num exame da próstata por RM, são normalmente realizados 4 tipos de estudos: morfológico, dinâmico perfusional, por difusão e espectroscópico da próstata. O estudo morfológico é útil para visualizar a arquitectura zonal da próstata. Isto é feito através das sequências com ponderação T1 e T2 Turbo Spin Eco (TSE) (Figura 1). Numa sequência ponderada em T1, a próstata surge com um sinal muito uniforme de intensidade intermédia enquanto, na sequência T2, observam-se diferenças nas regiões da glândula: a região periférica surge com hiperintensidade em contraste com a zona central e de transição que apresentam uma intensidade de sinal mais reduzida $[3,5,6]$.

O estudo dinâmico perfusional é realizado com recurso a um agente de contraste endovenoso de gadolíneo e 
angiogenesis. The contrast will accumulate in the tumor area because it is an area of high blood supply. A T1weighted sequence with fat suppression is used (Figure 2), where an increase in signal intensity from that area can be observed and which can be demonstrated graphically.

A diffusion-weighted sequence studies the random motion of water molecules in tissue. In cancer tissues, the diffusion coefficient is low, which means that the movement of water molecules in that specific tissue is restricted in comparison to normal tissue. This results from increased tissue cellularity, a decrease in the extracellular space and / or alteration of cell permeability. Through MRI, a suspicious area can be detected if it presents a considerable number of voxels below the threshold of $1.07 \times 10^{-3} \mathrm{~mm}^{2} / \mathrm{s}[3,7]$.

MRS provides information about the prostate by showing the relative concentration of metabolites. Thus, it becomes possible to obtain information about the presence of metabolites that are distributed in the cytosol and on the extracellular environment of the cells which determines if there are any abnormal changes in their concentration. In this type of study, emphasis is given to the concentrations of $\mathrm{Cho}$ and $\mathrm{Ci}$. A normal prostate tissue contains a high concentration of Cho and a low concentration of $\mathrm{Ci}$ (Figure 2) [4]. Since $\mathrm{Ci}$ is a metabolite normally secreted by the prostate gland and Cho a metabolite associated with cell membranes, it is expected that in a tumor $\mathrm{Ci}$ concentrations diminish due to a disrupted glandular function and that Cho concentrations increase due to an increase in cellular turno-over [4]. In neoplastic tissues, the ratio Cho / $\mathrm{Ci}$ is increased (>1.5) compared to normal tissues, which may be a useful indicator for the PCa diagnosis [3, 4]. baseia-se na neoangiogénese do tumor. $\mathrm{O}$ contraste vai acumular-se na zona do tumor por ser uma zona com elevado aporte sanguíneo. É utilizada uma sequência T1 TSE com saturação de gordura, na qual se verificará um incremento na intensidade do sinal dessa zona (Figura 2) que é demonstrado graficamente [3].

O estudo por difusão estuda o movimento aleatório das moléculas de água nos tecidos. Em tecidos neoplásicos, o coeficiente de difusão é baixo, o que significa que o movimento das moléculas de água, nesse tecido específico, se encontra restringido em comparação com um tecido normal. Este facto pode ser devido a uma maior celularidade tecidual, a uma diminuição do espaço extracelular e/ou alteração da permeabilidade celular. Através da imagem em RM, uma área suspeita pode ser detectada se apresentar um conjunto considerável de voxeis abaixo do limiar de $1,07 \times 10^{-3} \mathrm{~mm}^{2} / \mathrm{s}[3,7]$.

A MRS fornece informação sobre a próstata a nível da concentração relativa de metabolitos. Assim, torna-se possível obter informação sobre a presença de metabolitos distribuídos no citosol e no meio extracelular das células, determinando se existem alterações anormais de concentração. Neste tipo de estudo, é dado ênfase às concentrações de Cho e Ci. Um tecido prostático normal contém uma concentração elevada de $\mathrm{Ci}$ e baixa de Cho (Figura 2) [4]. Sendo o Ci um metabolito normalmente secretado pela glândula e a Cho um metabolito associado às membranas celulares, é de esperar que num tecido neoplásico as concentrações de $\mathrm{Ci}$ baixem devido a comprometimento da função glandular e que as concentrações de Cho aumentem devido ao aumento do turn-over celular [4]. Em tecidos neoplásicos, o rácio Cho/Ci está aumentado $(>1,5)$ comparativamente aos tecidos normais e pode ser um indicador útil para o diagnóstico de AdP [3, 4].

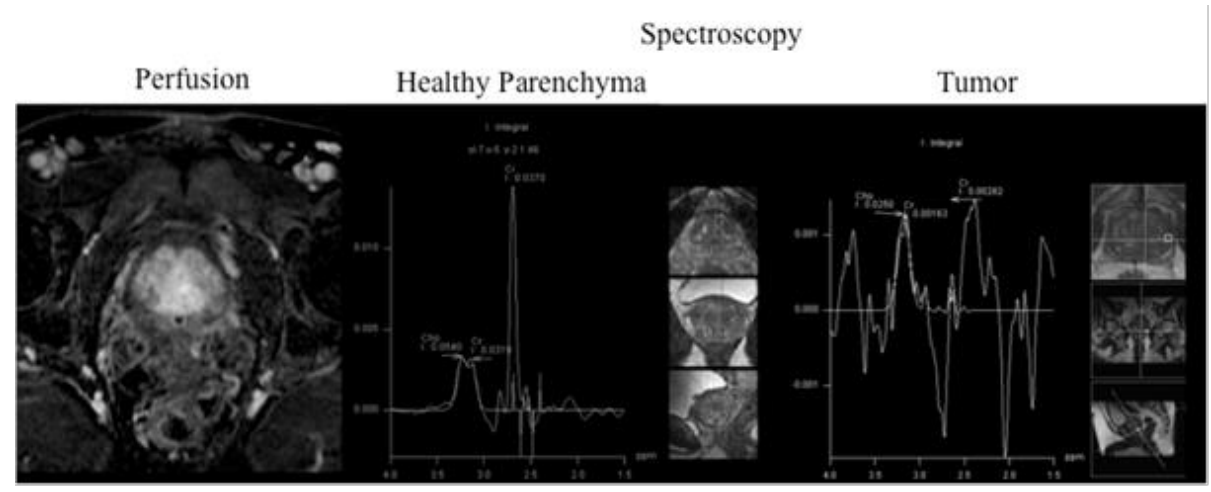

Figure 2 / Figura 2 - Perfusion-weighted imaging: T1-weighted image with fat suppression acquired after intravascular administration of a gadolinium-based contrast agent (left). Spectrum obtained in peripheral parenchyma of the prostate gland and in tumor; anatomical localization of the spectroscopy voxel visualized in the axial, coronal and sagittal planes (right). Imagem ponderada em perfusão: imagem ponderada em T1 com supressão de gordura adquirida após administração endovenosa com agente de constrante de gadolíneo (à esquerda). Espectro obtido em parênquima da glândula prostática periférica saudável e em lesão tumoral; localização anatómica do voxel disposto em imagens axial, coronal e sagital (à direita). 


\section{Material and Methods}

This study is defined as descriptive and correlational. The target population consisted of 30 patients aged between 47 and 86 years who underwent an MRI due to prostate pathology, from May 2007 to January 2008. Examinations were conducted at the Clinic Dr. João Carlos Costa in Viana do Castelo, in the equipment Magnetom Trio 3T (Siemens, Erlangen). Two patients were excluded from this study because they did not do a spectroscopic study and 10 were excluded for not having a biopsy result. As a result, the study included 18 patients. Of the 18 patients, 6 had calculated PSA values, one of which had a very low value $(2.5 \mathrm{ng} / \mathrm{mL}), 4$ patients had low values $(3.5 \mathrm{ng} / \mathrm{mL}-4.0 \mathrm{ng} / \mathrm{mL})$ and 1 of the patients had a very high PSA value $(20 \mathrm{ng} / \mathrm{mL})$, according to table 1; 9 had known values of GS (from 6 to 9). All the patients that underwent a biopsy procedure have a known histological diagnosis: 11 patients had prostate adenocarcinoma, 4 patients had chronic prostatitis and 3 had a negative histological result.

\section{Material e Métodos}

Este estudo define-se como descritivo e correlacional. A população alvo é constituída por 30 doentes com idade compreendida entre os 47 anos e os 86 anos que foram submetidos a um exame de RM devido a patologia da próstata, entre Maio de 2007 a Janeiro de 2008. Estes exames foram efectuados na Clínica Dr. João Carlos Costa em Viana do Castelo, num equipamento SIEMENS MAGNETOM TRIO de 3T. Dois doentes foram excluídos deste estudo por não apresentarem estudo espectroscópico e 10 foram excluídos por não apresentarem resultado de biópsia. Como resultado, a amostra em estudo foi de 18 doentes.

Dos 18 doentes, 6 apresentavam valores de PSA, em que 1 doente apresentava um valor muito baixo $(2,5 \mathrm{ng} / \mathrm{mL})$, 4 doentes com valores baixos $(3,5 \mathrm{ng} / \mathrm{mL}-4,0 \mathrm{ng} / \mathrm{mL})$ e 1 doente com um valor muito elevado $(20 \mathrm{ng} / \mathrm{mL})$, de acordo com a Tabela 1; 9 apresentavam valores de GS (entre 6 a 9); 18 realizaram biópsia à próstata, sendo que, em 18 doentes, se conhece o diagnóstico histológico. Relativamente ao resultado de diagnóstico, 11 doentes apresentam AdP, 4 apresentam prostatite crónica e 3 doentes apresentam um resultado histológico negativo.

Table 1 / Tabela 1 - Probability of PCa based on total PSA (ng/mL) [10]. Probabilidade de AdP tendo por base os valores totais de PSA (ng/mL) [10].

\begin{tabular}{cc} 
Total PSA (ng/mL) & $\begin{array}{c}\text { Probability (\%) } \\
\text { Probabilidade }\end{array}$ \\
\hline PSA total (ng/mL) & $<2 \%$ \\
\hline$<2.5 \mathrm{ng} / \mathrm{ml}$ & $18 \%$ \\
\hline $2.5 \mathrm{a} 4.0 \mathrm{ng} / \mathrm{ml}$ & $25 \%$ \\
$4 \mathrm{a} 10 \mathrm{ng} / \mathrm{ml}$ & $67 \%$ \\
\hline$>10 \mathrm{ng} / \mathrm{ml}$ &
\end{tabular}

Regarding MRI examination, patients underwent morphological studies using the following sequences: T1 TSE Sagittal, and T2 TSE in the Sagittal, Coronal and Axial planes for morphology; a MRS study (TR/TE = 750/145 ms) using a Chemical Shift Imaging (CSI) 3D Spin Echo (SE) sequence; and a diffusion study using a Diffusion Weighted Imaging (DWI) SE sequence with a Echo Planar Imaging (EPI) reading $\left(\mathrm{b}=0 \mathrm{~s} / \mathrm{mm}^{2}\right.$, $500 \mathrm{~s} / \mathrm{mm}^{2} 1000 \mathrm{~s} / \mathrm{mm}^{2}$ with 3 orthogonal directions). In the MRS study, Cho / Ci ratios were measured for 3 voxels in healthy central parenchyma, 3 voxels in healthy peripheral parenchyma and also 3 voxels in suspected lesion regions. Three voxels were chosen in order to make the average values of ratio $\mathrm{Cho} / \mathrm{Ci}$ for each region mentioned above.

In the diffusion study, the ADC values corresponding to the regions mentioned above were measured by placing circular Regions-of-Interest (ROIs) in the ADC
Em termos de estudos realizados por RM, os 18 doentes efectuaram estudos morfológicos utilizando as seguintes sequências: T1 TSE Sagital, T2 TSE Sagital, Coronal e Axial; efectuaram ainda um estudo de espectroscopia, utilizando a sequência Chemical Shift Imaging (CSI) 3D Spin Echo (SE) (TR/TE=750/145 ms); um estudo por difusão, utilizando a sequência diffusion weighted imaging (DWI) SE com leitura Eco Planar Imaging (EPI) (foram utilizados valores de $\mathrm{b}=0 \mathrm{~s} / \mathrm{mm}^{2}$, $500 \mathrm{~s} / \mathrm{mm}^{2}, 1000 \mathrm{~s} / \mathrm{mm}^{2}$ e 3 direcções de gradientes de sensibilização à difusão ortogonais).

As variáveis analisadas foram recolhidas dos exames acima descritos. No estudo por Espectroscopia, mediram-se os valores de rácio $\mathrm{Cho} / \mathrm{Ci}$ de 3 voxeis da zona central da próstata, 3 voxeis da zona periférica da glândula em regiões potencialmente patológicas e outros 3 voxeis da periferia referentes a parênquima saudável. Foram escolhidos três voxeis de modo a 
maps using Osirix software. For each region, 3 ROIs were placed in order to calculate mean values of ADC. Statistical analysis was performed using the Statistical Package for Social Sciences (SPSS v20). Mean values \pm standard deviations were calculated for each variable and correlations were made between them. Tests were also carried out comparing mean values regarding location in the gland: central, peripheral, and lesion, and in relation to histological results: $\mathrm{PCa}$, chronic prostatitis and negative histology. Nonparametric statistics were used due to small group samples. Therefore the MannWhitney test and the Spearman correlation were used. The significance level was $5 \%$.

\section{Results}

Regarding patient demographic characterization: the negative histology group had a mean age of $(62.3 \pm 6.5)$ years and an age interval of 56 years - 69 years. The group with a diagnostic result of $\mathrm{PCa}$ had a mean age of $(70.10 \pm 12.46)$ years ( 47 years -86 years). Finally, the group with a diagnostic result of chronic prostatitis had a mean age (67.20 \pm 7.46$)$ years (61 years -78 years). Table 2 shows the mean values of ratio $\mathrm{Cho} / \mathrm{Ci}$ and ADC regarding histological diagnosis and localization in the gland. It was observed that in all the 3 groups there were higher values of $\mathrm{Cho} / \mathrm{Ci}$ and lower values of ADC corresponding to measurements in lesions sites. efectuar a média dos valores de rácio $\mathrm{Cho} / \mathrm{Ci}$ para cada zona referida anteriormente.

Do estudo por difusão, foi medido o valor de ADC de regiões correspondentes às acima mencionadas colocando Regionsof-Interest (ROI) circulares nos mapas de ADC usando o software Osiriz. Para cada região, foram colocados 3 ROI de forma a efectuar a média do valor de ADC.

A análise estatística foi realizada no programa Statistical Package for the Social Sciences (SPSS v20). Foram calculados valores médios \pm desvios-padrão das diferentes variáveis e realizadas correlações entre estas. Foram ainda realizados testes de comparação de valores médios relativamente à localização na glândula: central, periférica com lesão ou saudável; e relativamente ao resultado histológico: AdP, prostatite crónica e histologia negativa.

Foram utilizados testes estatísticos não paramétricos, porque a amostra não cumpria os requisitos para a aplicação de testes paramétricos, nomeadamente, dado o seu tamanho reduzido, as variáveis apresentavam uma distribuição não normal. Desta forma, foram utilizados testes de Mann-Whitney e correlações de Spearman. O nível de significância utilizado foi de $5 \%$.

\section{Resultados}

Primeiramente, procedeu-se a caracterização demográfica da amostra em estudo. Esta é homogénea em termos de género e idade, sendo dividida em 3 grupos distintos consoante o diagnóstico histológico. $\mathrm{O}$ grupo com histologia negativa apresenta uma média de idades de $(62,3 \pm 6,5)$ anos e intervalo de idades de 56 anos - 69 anos. O grupo com resultado de diagnóstico de AdP apresenta uma média de idades $(70,10 \pm 12,46)$ anos (intervalo de 47 anos - 86 anos). Por fim, o grupo com resultado de diagnóstico de prostatite crónica apresenta uma média de idades $(67,20 \pm 7,46)$ anos (intervalo 61 anos -78 anos).

A Tabela 2 mostra os valores médios de $\mathrm{Cho} / \mathrm{Ci}$ e $\mathrm{ADC}$ segundo o diagnóstico histológico e localização na glândula.

Table 2 /Tabela 2 - Comparative table of mean \pm standard deviation values of Cho / $\mathrm{Ci}$ and ADC belonging to the groups with the diagnosis of $\mathrm{PCa}$, chronic prostatitis and negative histology, in the different regions of the prostate ( $\mathrm{n}=$ number of cases).

Tabela comparativa de valores médios \pm desvio-padrão de Cho / Ci e ADC de diferentes grupos diagnósticos AdP, prostatite crónica e histologia negativa, em diferentes regiões da próstata ( $\mathrm{n}=$ número de casos).

\begin{tabular}{|c|c|c|c|c|c|c|}
\hline \multirow[b]{2}{*}{$\begin{array}{c}\text { Diagnóstico/ } \\
\text { Diagnosis }\end{array}$} & \multicolumn{3}{|c|}{$\mathrm{Cho} / \mathrm{Ci}$} & \multicolumn{3}{|c|}{$\mathrm{ADC} /\left(10^{-3} \mathrm{~mm}^{-2} \mathrm{~s}^{-1}\right)$} \\
\hline & $\begin{array}{l}\text { Periferia/ } \\
\text { Periphery }\end{array}$ & Central & $\begin{array}{l}\text { Lesão/ } \\
\text { Lesion }\end{array}$ & $\begin{array}{l}\text { Periferia/ } \\
\text { Periphery }\end{array}$ & Central & $\begin{array}{l}\text { Lesão/ } \\
\text { Lesion }\end{array}$ \\
\hline $\begin{array}{c}\text { Histologia } \\
\text { Negativa/ } \\
\text { Negative } \\
\text { Histology } \\
\quad(n=3)\end{array}$ & $\begin{array}{c}0,413 \pm \\
0,030\end{array}$ & $\begin{array}{c}0,327 \pm \\
0,243\end{array}$ & $\begin{array}{c}1,780 \pm \\
0,975\end{array}$ & $\begin{array}{c}1,755 \pm \\
0,063\end{array}$ & $\begin{array}{c}1,383 \pm \\
0,212\end{array}$ & $\begin{array}{c}1,358 \pm \\
0,483\end{array}$ \\
\hline $\begin{array}{c}\text { AdP/PCa } \\
\quad(n=11)\end{array}$ & $\begin{array}{c}0,441 \pm \\
0,190\end{array}$ & $\begin{array}{c}2,564 \pm \\
3,060\end{array}$ & $\begin{array}{c}9,368 \pm \\
7,229\end{array}$ & $\begin{array}{c}1,547 \pm \\
0,156\end{array}$ & $\begin{array}{c}1,395 \pm \\
0,204\end{array}$ & $\begin{array}{c}0,960 \pm \\
0,172\end{array}$ \\
\hline $\begin{array}{c}\text { Prostatite } \\
\text { Crónica/ } \\
\text { Chronic } \\
\text { Prostatitis } \\
\quad(n=4)\end{array}$ & $\begin{array}{c}0,559 \pm \\
0,120\end{array}$ & $\begin{array}{c}0,753 \pm \\
0,882\end{array}$ & $\begin{array}{c}3,265 \pm \\
1,625\end{array}$ & $\begin{array}{c}1,374 \pm \\
0,372\end{array}$ & $\begin{array}{c}1,566 \pm \\
0,296\end{array}$ & $\begin{array}{c}1,108 \pm \\
0,053\end{array}$ \\
\hline
\end{tabular}


It was also observed that the highest and lowest values of Cho / $\mathrm{Ci}$ and $\mathrm{ADC}$ respectively, corresponded to the histological diagnosis of PCa (Figure 3). It was observed that the mean values of $\mathrm{Cho} / \mathrm{Ci}$ and $\mathrm{ADC}$ for the peripheral healthy parenchyma are similar
Observou-se que os valores mais elevados de $\mathrm{Cho} / \mathrm{Ci}$ e mais baixos de ADC correspondem a medições nas lesões para qualquer grupo de diagnóstico.

Também se constatou que os valores mais elevados de $\mathrm{Cho} / \mathrm{Ci}$ e mais baixos de ADC correspondem ao diagnóstico histológico de AdP (Figura 3).
MRS

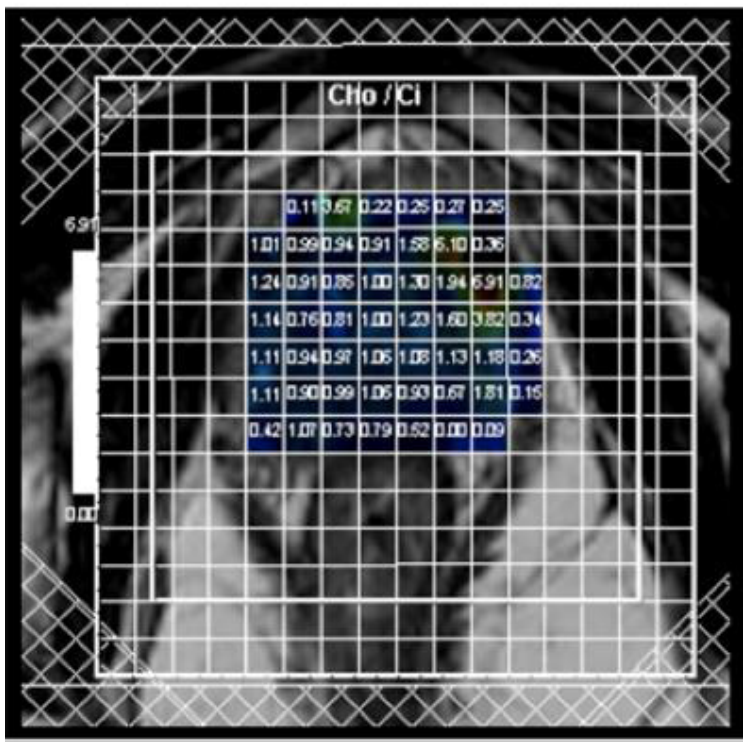

DWI $b=1000 \mathrm{~s} / \mathrm{mm}^{2}$

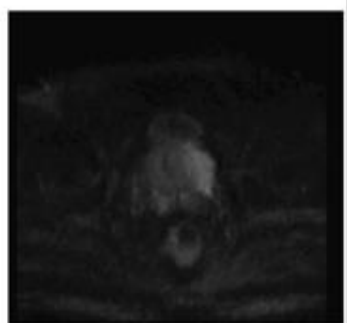

ADC

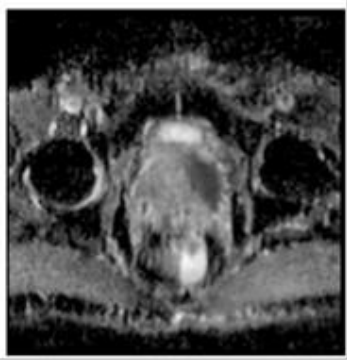

Figure 3 / Figura 3 - Cho / Ci ratio map: in each individual voxels the ratio is represented numerically and also by a color; tumor lesion in hot colors (left). Diffusion-weighted image $\left(b=1000 \mathrm{~s} / \mathrm{mm}^{2}\right)$ and Apparent Diffusion Coefficient map; the same tumor lesion shows restriction to water diffusion (right).

Mapa espectral de rácio Cho / Ci: em cada voxel o rácio está representado numericamente e também por cor; a lesão tumoral apresenta-se em cores quentes (à esquerda). Imagem ponderada em difusão $\left(b=1000 \mathrm{~s} / \mathrm{mm}^{2}\right)$ e mapa de coeficiente de difusão aparente; $a$ mesma lesão tumoral mostra restrição à difusão (à direita).

in all 3 groups. In the diagnostic group of $\mathrm{PCa}$, there were statistically significant differences between the mean values of $\mathrm{Cho} / \mathrm{Ci}(p=0.000)$ and $\mathrm{ADC}(p=0.000)$ between lesions and healthy parenchyma (Figures 4 and 5, respectively). We also observed significant differences between the mean values of lesions and of central gland regions Cho / $\mathrm{Ci}(p=0.004)$ and $\mathrm{ADC}(p$ $=0.000)$. Comparing the mean values of $\mathrm{Cho} / \mathrm{Ci}$ in the central region with peripheral parenchyma, there was a statistically significant difference $(p=0.023)$ which was not seen in the mean values of $\operatorname{ADC}(p=0.161)$. Regarding the group with a chronic prostatitis diagnosis, there was a statistically significant difference $(p=$ 0.029 ) between the mean values of $\mathrm{Cho} / \mathrm{Ci}$ in lesions and the healthy peripheral parenchyma. Concerning the negative histology group, differences were observed between the mean values of $\mathrm{Cho} / \mathrm{Ci}$ in suspected lesions and in healthy peripheral parenchyma $(p=0.006)$. Afterwards, correlations were made between the different variables and the histological diagnosis of PCa. It
Observou-se que os valores médios de Cho / $\mathrm{Ci}$ e de ADC para o parênquima periférico saudável são semelhantes nos três grupos. No grupo de diagnóstico de AdP, observaram-se diferenças estatisticamente significativas entre os valores médios de Cho/Ci $(p=0,000)$ e ADC $(p=0,000)$ entre a região de lesão e a região de parênquima saudável (Figuras 4 e 5 , respectivamente). Observaram-se ainda diferenças estatisticamente significativas entre os valores médios da região da lesão e da zona central, relativamente a $\mathrm{Cho} / \mathrm{Ci}(p=0,004)$ e ADC $(p=0,000)$. Comparando os valores médios de Cho / Ci da região central com o parênquima saudável verificou-se uma diferença estatisticamente significativa $(p=0,023)$, mas não relativamente aos valores médios de ADC $(p=0,161)$. Relativamente ao grupo de diagnóstico de prostatite crónica, observou-se uma diferença estatisticamente significativa $(p=0,029)$ entre os valores médios de $\mathrm{Cho} / \mathrm{Ci}$ da região da lesão e da região do parênquima saudável. Relativamente ao grupo com diagnóstico histológico negativo, observouse diferenças entre os valores médios de $\mathrm{Cho} / \mathrm{Ci}$ na lesão e no parênquima saudável $(p=0,006)$. Posteri- 
was observed that the correlation between the values of $\mathrm{Cho} / \mathrm{Ci}$ in the peripheral zone and the values of GS is positive and moderately strong $(r=0.677, p=0.045)$ (Figure 6). There was no statistically significant correlation between the values of $\mathrm{Cho} / \mathrm{Ci}$ in the periphery and healthy parenchyma $(p=0.666)$. The remaining correlations between variables and the negative histological diagnosis and chronic prostatitis diagnosis were not statistically significant. ormente efectuaram-se correlações entre as diferentes variáveis com diagnóstico histológico de AdP. Foi observado que a correlação entre os valores de $\mathrm{Cho} / \mathrm{Ci}$ na zona periférica e os valores de GS é positiva e moderadamente forte $\left(r_{\mathrm{s}}=0,677 ; p=0,045\right)$ (Figura 6). Não foi observada correlação estatisticamente significativa entre os valores de Cho/Ci na periferia e no parênquima saudável $(p=0,666)$. As restantes correlações entre as diferentes variáveis com o diagnóstico histológico negativo e de prostatite crónica também não foram estatisticamente significativas.

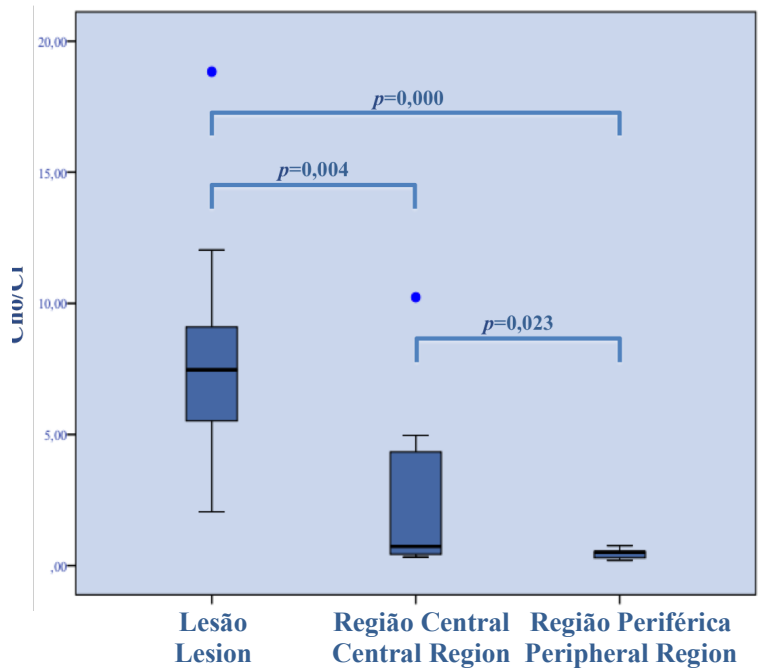

Figure 4 / Figura 4 - Box plot of values of $\mathrm{Cho}$ / $\mathrm{Ci}$ in different regions of the prostate for histological diagnosis of PCa. It is indicated the statistical significance in mean values assessed by the Mann-Whitney test. It was observed statistically significant differences between the mean values of Cho / $\mathrm{Ci}(\mathrm{p}=0.000)$ of lesions and of healthy peripheral parenchyma, in agreement with the literature [4].

Diagrama de bigodes dos valores de Cho/Ci nas diferentes zonas da próstata para diagnóstico histológico de AdP. É indicada a significância estatística da diferença de valores médios avaliada pelo teste de Mann-Whitney. Observam-se diferenças estatisticamente significativas entre os valores médios de $\mathrm{Cho} / \mathrm{Ci}(\mathrm{p}=0,000)$ entre a região de lesão e a região de parênquima saudável, em concordância com a literatura [4].

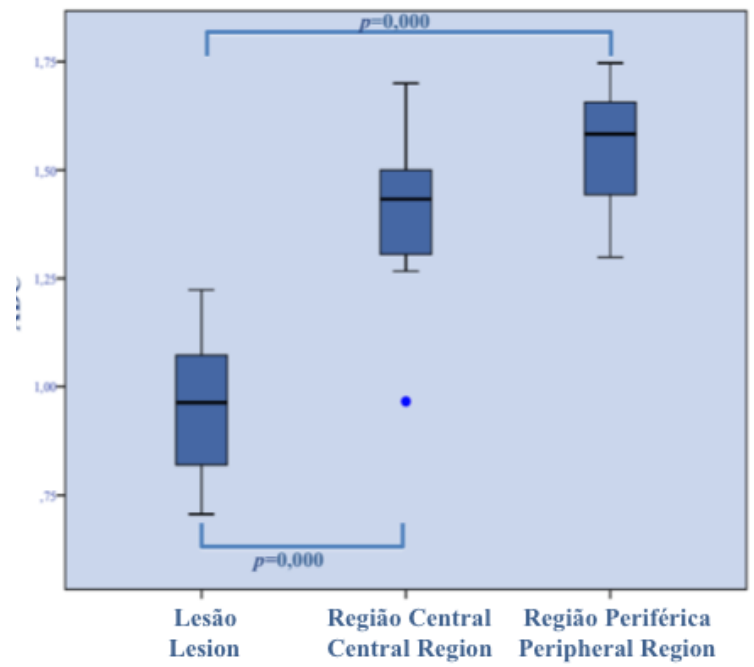

Figure 5 / Figura 5 - Box plot of values of Cho / Ci in different regions of the prostate for histological diagnosis of PCa. It is indicated the statistical significance in mean values assessed by the Mann-Whitney test. It was observed statistically significant differences between the mean values of ADC (in multiples of 10-3 mm2/s) of lesions and of healthy peripheral parenchyma, in agreement with the literature [4].

Diagrama de bigodes dos valores de ADC nas diferentes zonas da próstata para diagnóstico histológico de AdP. É indicada a significância estatística da diferença de valores médios avaliada pelo teste de Mann-Whitney. Observam-se diferenças estatisticamente significativas entre os valores médios de ADC (em múltiplos de 10-3 mm2/s ) entre a região de lesão e a região de parênquima saudável, em concordância com a literatura [4]. 


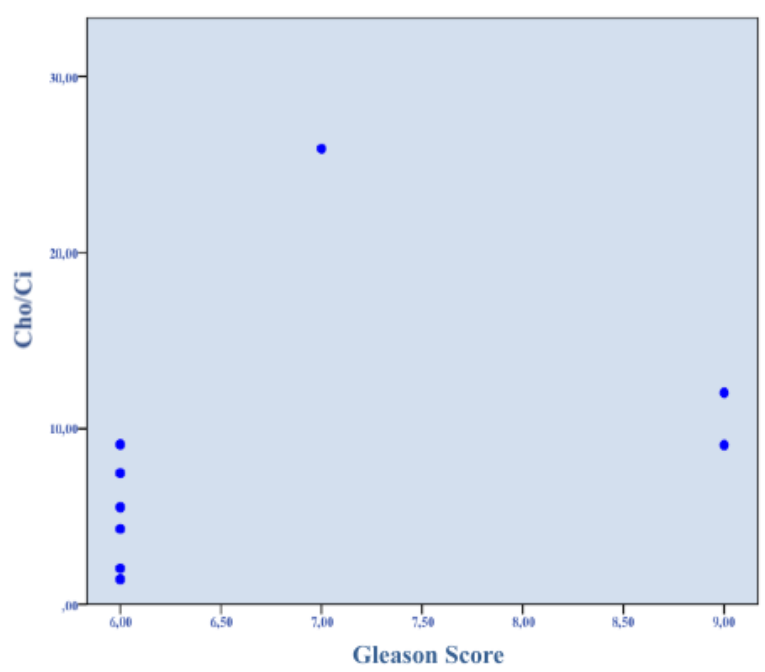

Figure 6 / Figura 6 - Scatter plot showing the correlation between the mean values of Cho / Ci for PCa lesions and the values of GS. It was observed that the correlation between these variables is positive and moderately strong ( $\mathrm{rS}=0.677$; $\mathrm{p}=0.045$ ), consistent with the fact that more aggressive tumors have less glandular function, increased production of membrane and increased undifferentiated tissue [9].

Gráfico de dispersão representativo da correlação dos valores médios de Cho/Ci na zona de lesão com os valores de GS. Foi observado que a correlação entre estas variáveis é positiva e moderadamente forte $(\mathrm{rS}=0,677 ; \mathrm{p}=0,045)$, concordante com o facto que tumores mais agressivos apresentam menor função glandular, maior produção de membrana e maior indiferenciação tecidular [9].

\section{Discussion}

The statistical analysis revealed that there are significant differences between the mean values of ADC and Cho / $\mathrm{Ci}$ in the lesion sites compared to the healthy parenchyma in the $\mathrm{PCa}$ diagnostic group, in agreement with the literature [4]. Comparing the mean values of Cho / $\mathrm{Ci}$ of the central region and the peripheral healthy parenchyma, there was a statistically significant difference which was not observed in the mean values of ADC. Knowing that the central and peripheral zones of the gland are functionally distinct, it can be expected that they have different metabolic ratios [4]. However, the tissue cellularity does not appear to be very different as assessed by the ADC parameter [8]. Statistically significant differences were observed between the mean values of $\mathrm{Cho} / \mathrm{Ci}$ and $\mathrm{ADC}$ of lesions and the central zone of the gland, for the same reasons stated above. Concerning the group with the diagnosis of chronic prostatitis, there was a statistically significant difference between the mean values of $\mathrm{Cho} / \mathrm{Ci}$ in the region of the lesion and the healthy parenchyma region. This shows that this technique allows us to differentiate inflammatory changes. In patients with negative histology diagnosis, it was observed that there were differences between the values of $\mathrm{Cho} / \mathrm{Ci}$ of the lesion area and of the healthy parenchyma. This could mean that the evaluated tissue may be altered or that it can be a tumor that was not detected by the biopsy, which is consistent with the limitations in sensitivity of the technique [2].

Subsequently, correlations were made between the different variables with the histological diagnosis of PCa.

\section{Discussão}

Após análise estatística, observou-se que existem diferenças significativas entre os valores médios de ADC e Cho/Ci da lesão em comparação com o parênquima saudável, no grupo de diagnóstico de $\mathrm{AdP}$, em concordância com a literatura [4]. Comparando os valores médios de $\mathrm{Cho/Ci}$ da região central com os do parênquima periférico saudável, verificou-se uma diferença estatisticamente significativa, mas não relativamente aos valores médios de ADC. Sabendo que as zonas central e periférica da glândula são funcionalmente distintas, será aceitável que tenham rácios metabólicos diferentes [4]. Contudo a celularidade dos tecidos não parece ser muito diferente tal como avaliada pelo parâmetro ADC [8]. Observaram-se diferenças estatisticamente significativas entre os valores médios da região da lesão e da zona central da glândula, relativamente à $\mathrm{Cho} / \mathrm{Ci}$ e $\mathrm{ADC}$, pelos mesmos motivos acima apontados. Relativamente ao grupo de diagnóstico de prostatite crónica, observou-se uma diferença estatisticamente significativa entre os valores médios de $\mathrm{Cho} / \mathrm{Ci}$ da região da lesão e da região do parênquima saudável, mostrando que a técnica permite diferenciar alterações inflamatórias. Nos doentes com histologia negativa, observou-se diferenças entre os valores médios de Cho/ $\mathrm{Ci}$ da lesão e do parênquima saudável. O tecido avaliado poderá estar alterado ou ser uma lesão tumoral que não foi detectada pela biópsia, em concordância com as limitações da sensibilidade da técnica [2].

Posteriormente efectuaram-se correlações entre as difer- 
It was observed that the correlation between $\mathrm{Cho} / \mathrm{Ci}$ in lesions and the values of GS is statistically significant, which is consistent with the fact that more aggressive tumors have less glandular function, increased production of membrane and increased undifferentiated tissue [9]. No correlation was observed between the valuesof Cho / $\mathrm{Ci}$ in the lesion and the values of $\mathrm{Cho} / \mathrm{Ci}$ of the healthy parenchyma, indicating that both variables are independent. The remaining correlations between the different variables with histologically negative and chronic prostatitis diagnosis were not statistically significant.

Finally, it is important to mention the limitations of this study. It was carried out on a small sample and on a group of patients without biopsy results, factors that may limit the significance of the results.

\section{Conclusion}

In this study, despite the limitation in terms of size of the sample, the results were in general in accordance with what is described in the literature. Thus, it is concluded that currently the MRI technique presents reliable criteria to identify and locate suspicious lesions and prostate tumors, with potential for guiding a biopsy in the diagnosis of PCa. In the future, it may be interesting to take another approach that focuses on the detection of the degree of malignancy of the tumor using MRI.

With the evolution of MRI and with widespread medical acceptance, this technique can actually be put into practice in the Portuguese clinical environment.

\section{Acknowledgements}

We thank the support from Clínica Dr. João Carlos Costa's radiographers Diana Martins and Marisa Gonçalves for data acquisition and collection. We appreciate the support provided by the head Coordinator of the Radiology course of the Escola Superior de Saúde Ribeiro Sanches (ERISA), Prof. Ana Luisa Vieira. We also acknowledge Prof. Paulo Pereira for the fruitful discussions concerning this work.

\section{Conflict of interests}

The authors declare that there are no financial and / or personal relations that could be viewed as a potential conflict of interests. entes variáveis com diagnóstico histológico de AdP. Foi observado que a correlação entre $\mathrm{Cho} / \mathrm{Ci}$ na zona periférica e os valores de GS é estatisticamente significativa, concordante com o facto que tumores mais agressivos apresentam menor função glandular, maior produção de membrana e maior indiferenciação tecidular [9]. Não foi observada correlação entre os valores $\mathrm{Cho/Ci}$ na lesão com os valores Cho/Ci no parênquima saudável, o que indica que ambas as variáveis são independentes. As restantes correlações entre as diferentes variáveis com diagnóstico histológico negativo e de prostatite crónica também não foram estatisticamente significativas.

Por fim, é de salientar as limitações deste estudo: o facto de se sustentar numa amostra reduzida e um grupo de doentes sem resultados de biópsia, factores que podem limitar a significância dos resultados obtidos.

\section{Conclusão}

Neste trabalho, apesar da limitação em termos de dimensão da amostra, os resultados obtidos foram na sua generalidade de encontro àquilo que se encontra descrito na literatura. Desta forma, conclui-se que actualmente a técnica de RM apresenta critérios de fiabilidade para identificar e localizar lesões tumorais e suspeitas na próstata, apresentando potencial para guiar a biópsia no diagnóstico de AdP. Futuramente poderá ser interessante uma outra abordagem que incida na detecção do grau de malignidade do tumor por RM.

Com a evolução da RM e com a aceitação médica generalizada, esta técnica poderá realmente ser colocada em prática no meio clínico nacional.

\section{Agradecimentos}

Agradecemos o apoio das técnicas de radiologia Diana Martins e Marisa Gonçalves da Clínica Dr. João Carlos Costa na aquisição e colheita de dados. Agradecemos ainda o apoio prestado pela Prof. Ana Luísa Vieira, coordenadora do curso de Radiologia da Escola Superior de Saúde Ribeiro Sanches (ERISA). Por fim, agradecemos ainda ao Prof. Paulo Pereira por discussões frutuosas a respeito do presente estudo e trabalho escrito.

\section{Conflito de interesses}

Os autores declaram que não existem relações finance ras ou pessoais que puderam ser vistas como um potencial conflito de interesses. 


\section{References / Referências}

[1] Portal de Oncologia Português - cancro da próstata. In http://www.pop.eu.com/portal/publico-geral/tipos-de-cancro/cancroda-prostata.html, acedido em/accessed in 27/06/2012.

[2] Futterer JJ et al. Prostate cancer localization with dynamic contrast-enhanced MR imaging and proton MR spectroscopic imaging. Radiology 2006; 241: 449-458.

[3] Passariello R et al. Imaging RM della prostata. Berlin: Springer; 2010, p. 25-34

[4] Kurhanewicz J. Spectroscopy of the prostate: MRS - Metabolite Profiling \& Metabolism. Proc. Intl. Soc. Mag. Reson. Med. 2011; 19. In http://cds.ismrm.org/ protected/11MProceedings/files/ ISMRM2011-8400.pdf acedido em/accessed in $27 / 06 / 2012$
[5] Westbrook C, Manual de Técnicas de Ressonância Magnética. $3^{\mathrm{a}} \mathrm{Ed}$, Rio de Janeiro: Guanabara Koogan Lda; 2009, p.12-35, 3442, 51-9, 312-22.

[6] Young JC et al. Functional MR imaging of prostate cancer. Radiographics 2007; 26: 63-77.

[7] Madabhushi A et al. Prostate cancer imaging: image analysis and image-guided interventions. Berlin: Springer; 2011, p. 88.

[8] Sato Chiho et al. Differentiation of noncancerous tissue and cancer lesions by Apparent Diffusion coefficient values in transition and peripheral zones of the prostate. Journal of Magnetic Resonance Imaging 2005; 21 : 258-262.
[9] Marques SS. Estudo dosimétrico prévio de irradiação da próstata com arco conformacional dinâmico. MSc Thesis, Faculdade de Ciências e Tecnologia da Universidade Nova de Lisboa; 2010. In http://run.unl.pt/ bitstream/10362/3958/1/Marques 2010.pdf, acedido em/accessed in 28/12/2011.

[10] Gretzer MB, Partin AW. PSA levels and the probability of prostate cancer on biopsy. European Urology Supplements 2002; 1: 21-27. 